\title{
Hubungan Asupan Energi Dan Tingkat Aktivitas Fisik Dengan Produktivitas Pada Tenaga Kerja Berstatus Gizi Lebih Bagian Packaging Di Pt Timur Megah Steel
}

\section{The Correlation Energy Intake and Physical Activity Level with Productivity Among Overweight Workers in Packaging section of PT. Timur Megah Steel}

\author{
Alfa Lailatul Maghfiroh*
}

\begin{abstract}
ABSTRAK
Latar Belakang: Produktivitas adalah kemampuan untuk menghasilkan barang dan jasa dengan memanfaatkan sumber daya yang dimiliki secara efisien. Tenaga kerja dengan produktivitas yang rendah dapat berpengaruh pada kemampuan dan hasil kerjanya. Produktivitas kerja dapat dipengaruhi oleh berbagai hal salah satunya yaitu asupan energi dan aktivitas fisik tenaga kerja. Kondisi gizi lebih yang dialami oleh tenaga kerja akan berpengaruh pada kondisi kesehatan dan kemampuan mobilitas sehingga dapat mempengaruhi kemampuan kerja dan produktivitas.

Tujuan: Menganalisis hubungan asupan energi dan tingkat aktivitas fisik dengan produktivitas pada tenaga kerja berstatus gizi lebih.

Metode: Penelitian ini merupakan penelitian observasional analitik dengan desain penelitian Cross sectional. Besar sampel sebanyak 22 orang dipilih secara simple random sampling. Data asupan energi didapatkan melalui kuesioner foodrecall $2 \times 24$ jam. Data aktivitas fisik didapatkan melalui kuesioner Baecke. Data produktivitas didapatkan dari pelaporan hasil kerja harian. Analisis statistik menggunakan uji korelasi pearson.

Hasil: Sebanyak 23\% responden memiliki status gizi overweight, $50 \%$ responden memiliki status gizi obesitas 1 , dan $27 \%$ responden memiliki status gizi obesitas 2 . Rata-rata asupan energi responden sebesar $2330,5 \pm 853$ kkal dan rata-rata indeks aktivitas fisik responden $7,5 \pm 1,59$. Berdasarkan analisis data diketahui bahwa terdapat hubungan antara asupan energi dengan produktivitas ( $p=0,001$ dan $r=0,660)$ terutama pada responden laki-laki $(p=0,020$ dan $r=0,716)$. Aktivitas fisik tidak berhubungan dengan produktivitas $(p=0,131)$.

Kesimpulan: Tenaga kerja yang memiliki asupan energi lebih tinggi memiliki produktivitas yang lebih baik terutama pada tenaga kerja laki-laki. Salah satu bentuk upaya perbaikan produktivitas kerja yaitu dengan menyediakan makanan sesuai kebutuhan energi bagi tenaga kerja di perusahaan. Upaya tersebut dapat dilakukan dengan menyelenggarakan pemberian makanan ataupun dengan menyediakan makanan sesuai kebutuhan di koperasi perusahaan.
\end{abstract}

Kata Kunci: produktivitas, asupan energi, aktivitas fisik, tenaga kerja.

\section{ABSTRACT}

Background: Productivity is the ability to produce goods and services using resources efficiently. Low worker productivity can affect the ability and results of their work. Work productivity can be influenced by various things, one of which is energy intake and physical activity of the workforce. Worker who has overweight and obesity can affect health conditions and mobility abilities so that they can affect work ability and productivity.

Objective: To analyze the correlation between energy intake and physical activity level with productivity in workers with overweight nutritional status.

Method: This research was observational analytic with design study cross sectional.22 samples were chosen by simple random sampling. Energy intake data was obtained through 24-hour foodrecall questionnaire. Physical activity data were obtained through Baecke questionnaire. Productivity data obtained from reporting results of daily work. Statistical analysis using Pearson correlation test.

Results: 23\% of respondents was overweight, 50\% of respondents was obesity 1, and 27\% of respondents was obesity 2 . Average energy intake of respondents was $2330.5 \pm 853 \mathrm{kcal}$ and average index of physical activity of respondents was 7.5 \pm 1.59 . There was a relationship between energy intake and productivity $(p=0.001$ and $r=0.660)$. There was not relationship between physical activity and productivity $(\mathrm{p}=0.129)$.

Conclusion: Workers who have higher energy intake have better productivity especially male workers. Work productivity improvement can be done by providing food according to energy needs for workers in the company. These efforts can be done by providing food or by providing food as needed in the company canteen. 
Keywords: productivity, energy intake, physical activity, workers.

Koresponden:

Alfa Lailatul Maghfiroh

alfa.lailatul.maghfiroh-2015@fkm.unair.ac.id

Departemen Gizi Kesehatan, FKM, Universitas Airlangga

\section{PENDAHULUAN}

Seiring dengan berkembangnya industri di Indonesia, sebagian besar penduduk Indonesia bekerja sebagai buruh atau karyawan ${ }^{1}$. Salah satu industri yang kini mulai berkembang yaitu industri manufaktur. Sebanyak $14 \%$ penduduk Indonesia bekerja sebagai buruh atau karyawan di industri manufaktur ${ }^{2}$. Tenaga kerja merupakan bagian penting dalam keberlangsungan sebuah industri. Namun, permasalahan kesehatan dan gizi tenaga kerja umumnya belum menjadi perhatian. Tenaga kerja dengan status kesehatan dan status gizi yang baik mampu bekerja dengan optimal dan memiliki produktivitas kerja yang baik.

Produktivitas kerja merupakan salah satu tolak ukur keberhasilan tenaga kerja dalam menghasilkan barang dan/atau jasa dalam waktu tertentu ${ }^{3}$. Tenaga kerja dinilai produktif apabila mampu menghasilkan barang dan /atau jasa lebih banyak daripada tenaga kerja lainnya ataupun lebih banyak dari target yang ditetapkan dalam waktu yang sama. Produktivitas dipengaruhi oleh berbagai hal. Salah satu hal yang dapat mempengaruhi produktivitas yaitu asupan energi dan aktivitas fisik.

Asupan energi bagi tenaga kerja mampu menentukan kondisi kesehatan dan kemampuan fisik dalam melakukan pekerjaannya ${ }^{4}$. Asupan energi yang tidak sesuai dengan kebutuhan dapat mengganggu aktivitas kerja sehingga dapat menurunkan produktivitas kerja.

Selain asupan energi, tingkat aktivitas fisik juga mempengaruhi produktivitas kerja. Aktivitas fisik mampu menentukan kondisi kesehatan tubuh secara keseluruhan ${ }^{5}$. Kondisi tubuh yang baik dapat meningkatkan produktivitas kerja. Berdasarkan survei aktivitas fisik pada dewasa menunjukkan bahwa proporsi populasi US dengan aktivitas rendah hingga sedang mencapai $25 \%$ dan $45 \%$ dilaporkan memiliki aktivitas fisik yang statis 6 . Aktivitas fisik yang rendah berakibat pada keluaran energi yang rendah, sehingga meningkatkan risiko terjadinya obesitas. Obesitas berakibat pada kerugian ekonomi yang dihasilkan dari menurunnya produktivitas kerja akibat sakit dan kematian dini $^{7}$.

PT. Timur Megah Steel merupakan industri yang bergerak dalam bidang manufaktur berupa pembuatan mur dan baut yang terletak di Driyorejo-Gresik. Jumlah tenaga kerja di bagian packaging sebanyak 64 orang. Sebanyak $47 \%$ tenaga kerja di bagian packaging mengalami gizi lebih. Bagian packaging di PT. Timur Megah Steel bertugas untuk mengemas produk jadi dalam kemasan. Proses packaging diawali dengan melakukan setting pada mur dan baut sesuai dengan pesanan. mur dan baut yang telah disetting kemudian dikemas dalam bag dan doz sesuai standar yang telah ditetapkan perusahaan. Sebagian besar kegiatan yang dilakukan di bagian packaging dilakukan dengan duduk. Oleh karena itu tenaga kerja dibagian packaging memiliki resiko mengalami gizi lebih.

Tujuan penelitian adalah menganalisis hubungan asupan energi dan aktivitas fisik dengan produktivitas pada tenaga kerja berstatus gizi lebih bagian packaging dengan di PT. Timur Megah Steel.

\section{METODE}

Penelitian ini merupakan penelitian observasional analitik dengan desain penelitian cross sectional. Populasi yang digunakan adalah tenaga kerja di PT. Timur Megah Steel Bagian Packaging dengan status gizi lebih sebanyak 30 orang. Penentuan sampel menggunakan rumus Lemeshow dengan nilai $p=0,06$ berdasarkan penelitian Butar (2017) . $^{2}$

Sehingga didapatkan sampel sebanyak 22 orang tenaga kerja ${ }^{9}$. Sampel penelitian diambil dari populasi penelitian dengan teknik simple random sampling.

Penelitian menggunakan data primer meliputi karakteristik responden (usia, jenis kelamin, Tingkat Pendidikan, lama kerja, dan pendapatan), asupan makanan, dan aktivitas fisik. Instrument yang digunakan meliputi kuesioner, form recall $2 \times 24$ jam, instrumen aktivitas fisik Baecke $^{10}$, timbangan digital, dan microtoise. Penelitian ini juga menggunakan data sekunder meliputi gambaran umum perusahaan dan hasil kerja dalam satu hari untuk menentukan produktivitas kerja. Hasil kerja kemudian dibandingkan dengan target hasil kerja berdasarkan Upah Minimum Regional UMR Kabupaten Gresik (Rp 3.867.874,40 per bulan atau Rp 148.764 per hari) dan dikategorikan menjadi baik apabila hasil kerja $\geq$ UMR Kabupaten Gresik dan kurang apabila hasil kerja < UMR Kabupaten Gresik $^{11}$. Untuk mendapatkan upah minimal per hari tersebut tenaga kerja pada bagian stapless harus mampu menghasilkan minimal 5.130 pcs box, bagian setting minimal 4250 pcs, packing doz menghasilkan 583 doz, dan packing doz mesin menghasilkan 4.960 doz.

Data hubungan asupan energi dan produktivitas kerja dianalisis menggunakan uji korelasi pearson. Data hubungan tingkat aktivitas fisik dan produktivitas dianalisis menggunakan uji Pearson

Penelitian ini telah lolos kaji etik dari Komite Etik penelitian kesehatan FKM Unair dengan nomor 109/EA/KEPK/2019.

\section{HASIL DAN PEMBAHASAN}

\section{Karakteristik Responden}

Responden yang diambil adalah tenaga kerja yang mengalami gizi lebih terdiri dari 10 orang laki-laki dan 12 orang perempuan. Berdasarkan Tabel 1 menunjukkan 
sebanyak $50 \%$ responden memiliki status gizi obesitas 1 . Usia responden berkisar antara 18 hingga 54 tahun dengan rata-rata usia responden yaitu 39 tahun. Sebanyak $41 \%$ responden berusia terkategori lansia awal. Seiring pertambahan usia akan terjadi pula penurunan fungsi anatomis dan fisiologis ${ }^{12}$. Begitu pula kemampuan metabolisme tubuh akan mengalami penurunan. Hal ini dapat menyebabkan terjadinya penurunan produktivitas kerja, sehingga dapat menurunkan pencapaian kerja.

Tabel 1. Karakteristik Responden

\begin{tabular}{lcc}
\hline \multicolumn{1}{c}{ Karakteristik Responden } & $\begin{array}{c}\text { Jumlah } \\
(\mathrm{n})\end{array}$ & $\begin{array}{c}\text { Persentase } \\
(\%)\end{array}$ \\
\hline Usia & & \\
Remaja akhir (17-25 tahun) & 4 & 18 \\
Dewasa awal (26-35 tahun) & 5 & 23 \\
Dewasa akhir (36-45 tahun) & 4 & 18 \\
Lansia Awal (46-55 tahun) & 9 & 41 \\
Tingkat Pendidikan & & \\
Tamat SD/MI/sederajat & 8 & 36 \\
Tamat SMP/MTS/sederajat & 4 & 18 \\
Tamat SMA/MA/SMK/sederajat & 10 & 46 \\
Tamat perguruan tinggi & 0 & 0 \\
Pengetahuan Gizi & & \\
Kurang (<60\%) & 6 & 27 \\
Cukup (60-80\%) & 11 & 50 \\
Baik (>80\%) & 5 & 23 \\
Status Gizi & & \\
Overweight & 5 & 23 \\
Obese 1 & 11 & 50 \\
Obese 2 & 6 & 27 \\
Lama kerja & & \\
$\geq 10$ Tahun & 10 & 45,5 \\
< 10 Tahun & 12 & 54,5 \\
Pendapatan & & \\
Kurang dari UMR ( $\leq 3.867 .874,40)$ & 18 & 81,8 \\
Lebih dari UMR (>3.867.874,40) & 4 & 18,2 \\
\hline
\end{tabular}

Tabel 2. Asupan Zat Gizi Responden

\begin{tabular}{llll}
\hline Variabel & Total & Laki-laki & Perempuan \\
& & & \\
\hline Analisis Asupan Zat Gizi & & $3050 \pm 479$ & $1730 \pm 581,4$ \\
Energi (kkal) & $2330,5 \pm 853$ & $150,75 \pm 24,9$ & $73,7 \pm 16$ \\
Protein (g) & $88,2(15,1 \%) \pm 25,8$ & $107,6 \pm 27,5$ & $74,6 \pm 26,3$ \\
Lemak (g) & $89,6(34,6 \%) \pm 31,1$ & $414,4 \pm 78,9$ & $234,8 \pm 96,2$ \\
Karbohidrat (g) & $316,4(50,3 \%) \pm 126$ & & \\
Tingkat Kecukupan Zat Gizi & & & 25 \\
Energi & & 80 & 75 \\
Lebih (\%) & 50 & 20 & 83,3 \\
Cukup (\%) & 50 & 100 & 16,7 \\
Protein & & 0 & 75 \\
Lebih (\%) & 90,9 & & 25 \\
Cukup (\%) & 9,1 & 80 & 16,7 \\
Lemak & & 20 & 83,3 \\
Lebih (\%) & 77,3 & 70 & \\
Cukup (\%) & 22,7 & 30 & \\
Karbohidrat & & & \\
Lebih (\%) & 40,9 & & \\
Cukup (\%) & 59,1 & & \\
\hline
\end{tabular}

Sebagian besar responden (46\%) memiliki tingkat Pendidikan SMA/MA/SMK/dan sederajat. Semakin baik tingkat pendidikan maka pola berpikir akan semakin baik. Apabila diterapkan dalam pemilihan makanan, seseorang dengan tingkat pendidikan yang baik akan lebih mampu untuk memilih makanan yang baik untuk dikonsumsi dan mampu memperhitungkan kebutuhan gizinya.

Tingkat pengetahuan gizi diperoleh melalui wawancara kuesioner kepada responden. Sebanyak 50\% responden memiliki tingkat pengetahuan gizi cukup. Pengetahuan gizi yang baik akan berpengaruh pada kememapuan untuk memilih bakan makanan yang baik sehingga mampu untuk memenuhi kebutuhan gizi secara tepat ${ }^{13}$. Semakin baik tingkat pengetahuan gizi seseorang diharapkan semakin baik pula status gizinya.

Pendapatan responden diketahui dari upah yang diperoleh responden sendiri dalam satu bulan. Pendapatan responden akan mempengaruhi daya beli makanan untuk dikonsumsi. Sebagian besar responden $(81,8 \%)$ memiliki kategori pendapatan kurang dari UMR Kabupaten Gresik. Meskipun sebagian besar tenaga kerja mendapatkan upah dibawah UMR Kabupaten Gresik dan tidak memadai untuk mencukupi kebutuhan namun sebagian besar tenaga kerja tidak merasa kecewa, mengeluh, atau melakukan protes. Tenaga kerja tetap melasanakan kewajibannya dengan baik karena berdasarkan kontrak kerja yang telah disetujui, tenaga kerja akan diberikan upah erdasarkan hasil kerjanya. Upah responden berkisar antara Rp 1.900 .000 hingga Rp 4.000.000 dengan rata-rata upah responden yaitu $R p$ 3.400.000. Upah berpengaruh pada daya beli selain itu tingkat upah juga berpengaruh positif terhadap produktivitas kerja ${ }^{14}$. Upah yang minim membuat pekerja cenderung memilih konsumsi makanan tidak sehat seperti makanan instan dan makanan tinggi karbohidrat untuk memenuhi kebutuhan kalorinya. Sehingga selain menurunkan produktivitas juga menimbulkan kondisi gizi lebih yang dialami oleh tenaga kerja. Menurunnya produktivitas kerja akan berdampak pada penurunan produktivitas perusahaan ${ }^{15}$. 


\section{Asupan Energi}

Asupan Energi pada penelitian ini diukur menggunakan food recall $2 \times 24$ jam. Berdasarkan Tabel 2 diketahui bahwa sebanyak setengah dari responden memiliki tingkat kecukupan asupan energi melebihi AKE dengan rata-rata asupan energi 2330,5 kkal. Asupan energi yang berlebihan akan menimbulkan rasa malas, mengantuk, dan menurunkan kecepatan kerja sedangkan konsumsi eneri yang kurang dari kebutuhan akan menurunkan konsentrasi sehingga dapat berakibat pada kecelakaan kerja utamanya bagi tenaga kerja yang membutuhkan konsentrasi penuh pada pekerjaannya ${ }^{16}$. Tenaga kerja yang mengonsumsi makanan yang cukup secara kualitas dan kuantitas akan memperoleh energi yang cukup sehingga memungkinkan bekerja dengan produktif ${ }^{17}$. Konsumsi energi pada tenaga kerja erat hubungannya dengan konsumsi sarapan yang menunjang kebutuhan energi pada saat memulai pekerjaan dan makan siang yang akan menunjang kebutuhan energi tenaga kerja dari siang hari hingga sore hari. Sebagian besar responden penelitian ini mengonsumsi sarapan sebelum berangkat kerja sedangkan untuk makan siang responden membawa bekal makanan dari rumah dikarenakan belum ada upaya penyelenggaraan makanan di perusahaan.

\section{Aktivitas Fisik}

Nilai aktivitas fisik pada penelitian ini diperoleh dari skor total indeks aktivitas fisik dalam kuesioner Baecke yang meliputi indeks kerja, indeks waktu luang, dan indeks olahraga. Aktivitas kerja dipengaruhi oleh jenis pekerjaan dan durasi kerja. Semakin berat beban kerja, maka direkomendasikan untuk memperpendek durasi kerja ${ }^{4}$. Hal tersebut dilakukan untuk menghindari resiko terjadinya kecelakaan kerja dan gangguan fisiologis akibat kelelahan. Aktivitas fisik juga memiliki pengaruh dengan tingkat kebugaran tubuh. Kondisi tubuh yang bugar akan berdampak pada kondisi fisik tubuh. Kebugaran tubuh tenaga kerja dapat dipengaruhi oleh aktivitas kerja dan aktivitas olahraga ${ }^{18}$. Berdasarkan Tabel 3 diketahui bahwa nilai rata-rata aktivitas fisik responden adalah 7.5. Tabel 3 menunjukkan dari 22 responden yang memiliki indeks aktivitas fisik kurang sebanyak $22.7 \%$ dan berat sebanyak $50 \%$. Sebagian besar aktivitas kerja dilakukan dengan duduk, namun sesekali responden mengangkat hasil produksi yang telah dikerjakan baik secara manual maupun dengan bantuan alat berat seperti katrol dan forklift. sehingga aktivitas kerja responden cukup berat. Terutama bagi responden pada bagan packing doz dan setting dikarenakan mereka harus sesekali.

Tabel 3. Aktivitas Fisik Responden

\begin{tabular}{llll}
\hline Variabel & Total & Laki-laki & Perempuan \\
\hline Analisis Aktivitas Fisik & & & \\
$\quad$ Indeks aktivitas kerja & $3,43 \pm 1,19$ & $2,9 \pm 0,75$ & $3,88 \pm 1,33$ \\
Indeks aktivitas olahraga & $1,84 \pm 0,398$ & $1,98 \pm 0,5$ & $1,73 \pm 0,25$ \\
Indeks aktivitas senggang & $2,22 \pm 0,9$ & $2,62 \pm 1,14$ & $1,89 \pm 0,48$ \\
Indeks Aktifitas Fisik & $7,5 \pm 1,59$ & $7,5 \pm 1,8$ & $7,5 \pm 1,47$ \\
Tingkat Aktivitas Fisik & & & \\
Kurang (\%) & 22,7 & 20 & 25 \\
Cukup (\%) & 27,3 & 40 & 16,7 \\
Berat (\%) & 50 & 40 & 58,3 \\
\hline
\end{tabular}

\section{Produktivitas}

Pada penelitian ini produktivitas diukur melalui hasil kerja dalam satu hari. Untuk mendapatkan upah sejumlah tersebut tenaga kerja minimal harus menghasilkan Rp 148.764 per hari. Untuk mendapatkan upah minimal per hari tersebut tenaga kerja pada bagian stapless harus mampu menghasilkan minimal 5.130 pcs box, bagian setting minimal 4250 pcs, packing doz menghasilkan 583 doz, dan packing doz mesin menghasilkan 4.960 doz. Hasil kerja diperoleh melalui data sekunder yang diperoleh dari administrasi perusahaan dan kemudian dilakukan penghitungan oleh peneliti. Seluruh responden pada penelitian ini adalah tenaga kerja borongan, sehingga pengupahan dilakukan berdasarkan hasil kerja. Tenaga kerja dikategorikan memiliki produktivitas yang baik apabila mampu menghasilkan Rp 148.764 dalam satu hari kerja ${ }^{11}$. Produktivitas responden dikategorikan menjadi terpenuhi dan tidak terpenuhi. Tabel 4 menunjukkan sebanyak $81.8 \%$ responden tidak memenuhi target hasil kerja. Rata-rata responden mampu menghasilkan $\mathrm{Rp}$ 105.207 setiap hari. Produktivitas kerja dipengaruhi oleh berbagai hal, salah satunya adalah asupan energi dan tingkat aktivitas fisik. Selain itu, produktivitas kerja dapat dipengaruhi oleh kompetensi, fasilitas kerja, motivasi kerja, dan pengalaman kerja ${ }^{19}$. Pada penelitian ini kompetensi, motivasi dan pengalaman kerja berperan penting dalam produktivitas kerja. Kuantitas hasil kerja juga dipengaruhi oleh motivasi tenaga kerja. Tenaga kerja yang memiliki motivasi untuk mendapatkan upah tinggi akan berusaha menghasilkan hasil kerja dengan jumlah tinggi meskipun harus bekerja over time.

Tabel 4. Hasil Kerja dan Produktivitas Responden

\begin{tabular}{llll}
\hline Variabel & Total & Laki-laki & Perempuan \\
\hline Analisis Hasil Kerja & & & \\
Produktivitas (Rp) & $105.727 \pm 46.248$ & $141.652 \pm 39.720$ & $75.789 \pm 25.328$ \\
Tingkat Produktivitas & & & \\
Tidak memenuhi (<Rp 148.764) (\%) & 86,4 & 70 & 100 \\
Memenuhi (>Rp 148.764) (\%) & 13,6 & 30 & 0 \\
\hline
\end{tabular}




\section{Hubungan Antar Variabel}

Berdasarkan Tabel 5 dapat diketahui bahwa hasil $p$ value 0,001 sehingga asupan energi berhubungan dengan produktivitas kerja utmanya tenaga kerja lakilaki dengan $p$ value 0,020 . Setengah dari responden telah mencukupi tingkat kecukupan energi berdasarkan AKG. Hasil tersebut sejalan dengan penelitian Astuti dan Puspowati (2017) menunjukkan terdapat hubungan signifikan antara asupan energi dengan produktivitas kerja $^{20}$. Hasil penelitian ini juga sejalan dengan penelitian yang dilakukan oleh Widyastuti (2011) dan Oktapianti (2014) yang menunjukkan bahwa terdapat hubungan antara asupan energi dengan produktivitas kerja ${ }^{21,22}$. Energi diperoleh dari konsumsi karbohidrat, lemak, dan protein ${ }^{17}$. Asupan energi tenaga kerja dapat mempengaruhi status gizi dan kemampuan kerja.

Asupan energi responden dihitung melalui metode food recall $2 \times 24$ jam. Asupan energi tenaga kerja pada saat bekerja diperoleh dari makanan yang dikonsumsi pada saat sarapan dan makan siang. Asupan energi untuk makan siang seharusnya diperoleh dari perusahaan berdasarkan surat edaran Menteri tenaga kerja dan transmigrasi tahun 1979 tentang pengadaan kantin dan ruang makan bagi tenaga kerja ${ }^{23}$. Namun, karena tidak dilakukannya penyelenggaraan makan di perusahaan sehingga tenaga kerja membawa bekal makanan dari rumah untuk memenuhi kebutuhan energi saat makan siang. Bekal makanan yang dibawa oleh tenaga kerja sesuai dengan kemampuan dan ketersediaan makanan di rumah masing-masing responden sehingga beberapa responden mengonsumsi makanan yang melebihi kebutuhan dan beberapa lainnya mengonsumsi makanan kurang dari kebutuhannya. Pemenuhan gizi yang baik akan berpengaruh secara langsung terhadap produktivitas kerja.

Aspek gizi merupakan salah satu bagian penting dari K3 yang secara tidak langsung akan mempengaruhi produktivitas kerja ${ }^{24}$. Asupan energi yang kurang dari kebutuhan akan berdampak pada terjadinya kelelahan kerja ${ }^{25}$. Asupan energi yang melebihi kebutuhan akan berdampak pada timbulnya rasa malas, mengantuk, dan menurunkan kecepatan kerja ${ }^{16}$. Oleh karena itu, tenaga kerja sebaiknya mengonsumsi energi sesuai dengan kebutuhannya.

Tabel 5. Hasil Analisis Hubungan Asupan Energi dan Aktivitas Fisik Responden dengan Produktivitas

\begin{tabular}{llllccc}
\hline Variabel & Total $p$-value & r-value & Laki-laki $p$-value & r-value & Perempuan $p$-value & r-value \\
\hline Aktivitas Fisik & 0,131 & - & 0,846 & - & 0,227 & - \\
Asupan Energi & 0,001 & 0,660 & 0,020 & 0,716 & 0,186 & - \\
\hline
\end{tabular}

*signifikan $\mathrm{p}<0$

Berdasarkan hasil analisis diketahui bahwa semakin tinggi asupan energi yang dikonsumsi, semakin tinggi pula produktivitas kerja responden utamanya tenaga kerja laki-laki. Hal tersebut dapat terjadi karena responden penelitian ini memiliki jenis kelamin heterogen yaitu terdiri dari laki-laki dan perempuan. Sebagian besar tenaga kerja perempuan berstatus gizi lebih memiliki usia lansia awal dan sebagian besar telah menyadari kondisi gizi lebih yang dialami serta resiko kesehatan yang dapat dialami akibat kondisi gizi lebih. Sehingga beberapa orang tenaga perempuan mengurangi asupan makan dari biasanya. Selain itu, perbedaan jenis kelamin responden berpengaruh pula pada kemampuan kerja. Tenaga kerja berjenis kelamin laki-laki memiliki kemampuan kerja yang lebih baik daripada perempuan karena memiliki tenaga yang lebih besar daripada perempuan ${ }^{26}$. Berdasarkan Tabel 2 diketahui bahwa tenaga kerja laki-laki cenderung memiliki asupan energi yang lebih tinggi dibandingkan dengan tenaga kerja perempuan. Berdasarkan table 5 juga dapat diketahui bahwa asupan energi laki-laki berpengaruh pada produktivitas kerja. Sedangkan asupan energi dan produktivitas tidak berhubungan bagi responden dengan jenis kelamin perempuan. Tabel 2 juga menunjukkan bahwa dari rata-rata asupan energi responden diketahui bahwa $34,5 \%$ dari asupan energi yang diasup bersumber dari lemak. Tingginya proporsi lemak dalam asupan sehari-hari responden dapat menjadi salah satu faktor terjadinya gizi lebih. Oleh karena itu, tenaga kerja sebaiknya mengonsumsi energi sesuai dengan kebutuhannya dan memperhatikan komposisi asupan makanannya.
Faktor lain yang dapat mempengaruhi produktivitas kerja adalah tingkat aktivitas fisik. Berdasarkan Tabel 5 maka dapat diketahui bahwa hasil $p$ value 0,131 yang menunjukkan aktivitas fisik dengan produktivitas kerja tidak berhubungan. Lebih dari setengah responden dengan tingkat aktivitas fisik kurang memiliki produktivitas kerja kurang baik. Aktivitas fisik yang kurang akan berpengaruh pada kebugaran jasmani tenaga kerja. Kebugaran jasmani adalah kemampuan tubuh seseorang untuk beradaptasi dengan beban fisik yang dihadapi tanpa menimbulkan efek Lelah yang berarti. Kelelahan kerja akan berdampak pada menurunnya produktivitas kerja. Berdasarkan hasil penelitian responden menyatakan bahwa kelelahan pasca kerja seringkali mereka alami. Rasa kelelahan yang umumnya sering dirasakan terutama pada bagian ekstrimitas seperti tangan dan kaki dikarenakan aktivitas kerja yang sebagian besar dilakukan dengan duduk dan melakukan packing barang dengan tangan. Sebagai upaya untuk megurangi rasa lelah, responden melakukan kegiatan tidur siang diwaktu istirahat dan waktu senggang sepulang kerja. Berdasarkan tabel 1 diketahui bahwa sebagian besar responden memiliki masa kerja cukup lama. Sehingga responden telah terbiasa dengan aktivitas kerja yang dilakukan setiap hari sehingga aktivitas kerja yang cukup berat tidak menimbulkan kelelahan berarti.

Pada penelitian ini mayoritas responden memiliki aktivitas kerja yang cukup berat dan homogen dikarenakan responden berada pada satu bagian yang sama namun aktivitas olah raga dan aktivitas senggang cukup rendah. Aktivitas olahraga yang rendah ditengarai oleh beberapa responden merasa tidak memiliki waktu 
untuk berolah raga dan tidak adanya fasilitas olahraga di perusahaan. Sebagian besar responden juga memiliki indeks aktivitas senggang yang rendah akibat gaya hidup sedentary yang dilakukan oleh responden, seperti berbaring dan menonton TV. Responden mengimbangi aktivitas kerja yang cukup berat dengan beristirahat di waktu senggangnya.

Aktivitas fisik yang rendah akan berdampak pada kondisi gizi lebih utamanya apabila diikuti dengan konsumsi energi melebihi kebutuhan. Status gizi lebih akan meningkatkan resiko penyakit tidak menular seperti penyakit jantung koroner, diabetes militus, hipertensi, kanker, dan lain sebagainya ${ }^{27}$. Selain itu, status gizi lebih juga berdampak pada penurunan fisiologis organ tubuh seperti otot dan paru-paru ${ }^{28}$. Kondisi gizi lebih dapat menyebabkan terjadinya nyeri dipersendian lutut. Terganggunya kondisi fisik akan mempengaruhi kemampuan kerja. Utamanya tenaga kerja yang menggunakan kemampuan fisik dalam melakukan pekerjaannya ${ }^{29}$. Beberapa responden yang berada dalam kategori usia lansia awal mengeluhkan mengalami permasalahan persendian. Namun, hal tersebut belum pada tahap yang mengganggu pekerjaanya dan menanganinya dengan memberikan koyo atau salep penghilang nyeri sehingga belum berada pada tahap yang mempengaruhi produktivitas kerja. Beberapa hal tersebut yang dapat mengakibatkan tidak adanya hubungan signifikan secara statistik. Hal tersebut sejalan dengan penelitian Sharifzadeh (2013) yang menyatakan bahwa tidak ada hubungan antara aktivitas fisik dengan produktivitas kerja ${ }^{30}$. Penelitian lain yang dilakukan oleh Oktapiyanti (2014) pada pekerja wanita di konveksi batik menunjukkan bahwa tidak ada hubungan yang signifikan antara aktivitas fisik dengan produktivitas pada tenaga kerja22.

Responden penelitian ini memiliki rentan usia yang cukup tinggi. Sebagian besar responden berada dalam kategori usia lansia awal. Usia dapat mempengaruhi kemempuan fisiologis dan anatomis tubuh ${ }^{12}$. Penurunan fungsi metabolisme zat dapat terjadi pada responden berusia lansia awal sehingga dapat meningkatkan resiko terjadinya gizi lebih. Selain itu usia juga mempengaruhi kemampuan untuk melakukan aktivitas fisik baik aktivitas kerja maupun aktivitas olahraga yang akan berpengaruh pada kemampuan kerja dan produktivitas kerjanya.

Pada saat penelitian dilakukan, terdapat beberapa keterbatasan penelitian yang ditemui diantaranya: data penelitian ini belum tentu dapat menggambarkan keseluruhan tenaga kerja PT. Timur Megah Steel karena hanya mengambil sampel pada tenaga kerja dengan gizi lebih di bagian packaging, Kemungkinan terjadi bias pada saat melakukan wawancara food recall dikarenakan beberapa responden berusia cukup tua terkategori lansia awal sehingga kesulitan untuk mengingat seluruh jumlah dan jenis makanan yang dikonsumsi.

\section{KESIMPULAN}

Hasil penelitian menunjukkan bahwa tenaga kerja yang memiliki asupan energi lebih tinggi memiliki produktivitas yang lebih baik. Namun, asupan energi perlu untuk diperhatikan terlebih dikarenakan responden memiliki status gizi lebih. Tingkat aktivitas fisik tidak mempengaruhi produktivitas kerja disebabkan oleh aktivitas kerja responden yang homogen.

Saran yang dapat diberikan sebagai bentuk upaya peningkatan produktivitas pekerja perlu dilakukan edukasi pada karyawan terkait pemenuhan asupan energi. Bentuk upaya edukasi bisa berupa penyuluhan berkala maupun pemberian leaflet dan penempelan poster terkait pemenuhan energi di lingkungan kerja. Selain itu penyediaan makanan di koperasi perusahaan perlu memperhatikan kebutuhan energi karyawan dalam sehari.

\section{ACKNOWLEDGEMENT}

Terima kasih disampaikan kepada pihak PT. Timur Megah Steel yang telah memberikan ijin melaksanakan penelitian di PT. Timur Megah Steel, serta kepada tenaga kerja bagian packaging yang telah bersedia menjadi responden penelitian

\section{REFERENS}

1. Statistik, B. P. Penduduk 15 Tahun Ke Atas Menurut Status Pekerjaan Utama 1986 - 2018. (2019). Available at: https://www.bps.go.id/statictable/2009/04/16/ 971/penduduk-15-tahun-ke-atas-menurutstatus-pekerjaan-utama-1986---2018.html.

2. Statistik, B. P. Proporsi Tenaga Kerja pada Sektor Industri Manufaktur, 2015 - 2016. (2017). Available at: https://www.bps.go.id/statictable/2009/04/16/ 971/penduduk-15-tahun-ke-atas-menurutstatus-pekerjaan-utama-1986---2018.html.

3. Hafner M, Van Stolk C, Saunders C, Krapels J, B. B. Health, wellbeing and productivity in the workplace. RAND Eur. (2015).

4. RI, K. Pemenuhan Kecukupan Gizi Bagi Pekerja. Available at:

http://www.kesmas.kemkes.go.id/portal/konte $\mathrm{n} /$ rilis-berita/021411-pemenuhan-kecukupangizi-bagi-pekerja. (Accessed: 22nd September 2019)

5. Standish, D. M. \& Hannon, M. No Title. (2016).

6. Dubbert, P. M. Physical Activity and Exercise: Recent Advances and Current Challenges. 70, 526-536 (2002).

7. Wulansari, A., Martianto, D. \& Baliwati, Y. F. ESTIMASI KERUGIAN EKONOMI AKIBAT OBESITAS. 11, 159-168 (2016).

8. BUTAR, M. M. B. Hubungan Status Gizi, Tingkat Asupan Energi, Beban Kerja Dengan Produktivitas Pekerja Wanita (Studi di PT Timur Megah Steel bagian Packaging). (Universitas Airlangga, 2017).

9. Lemeshow, S., Jr, D. W. H., Klar, J. \& Lwanga, S. K. Stanley Lemeshow, David W Hosmer Jr, Janelle Klar, and Stephen K. Lwanga. 
10. Baecke, J.A., Burema, J. and Frijters, J. E. A short questionnaire for the measurement of habitual physical activity in epidemiological studies. Am. J. Clin. Nutr. 36, 936-942 (1982).

11. Timur, P. P. J. Upah Minimum Sektoral Kabupaten/Kota Di Jawa Timur Tahun 2019. (2019).

12. Wikananda, G. Hubungan kualitas hidup dan faktor resiko pada usia lanjutdi wilayah kerja puskesmas tampaksiring I Kabupaten Gianyar Bali 2015. 8, 41-49 (2017).

13. Khomsan, A. Pangan dan Gizi untuk Kesehatan. (2007).

14. Nurfiat,Nashahta A., dan Rustariyuni, S. D. Pengaruh upah dan teknologi terhadap produktivitas dan penyerapan tenaga kerja pada industri mebel di kota denpasar. $J$. Kependud. dan Pengemb. Sumber Daya Mns. Vol. XIV, 34-48 (2018).

15. Krisnarini, D. \& Hubeis, M. Analisa Upah dan Kesejahteraan Pekerja Industri Kecil Menengah Pakaian Jeans XYZ di Pondok Aren, Tangerang Dwi Krisnarini , Musa Hubeis dan Ma'mun Sarma. 1-10 (2002).

16. Marsetyo, H. dan G. K. Ilmu Gizi. (Rineka Cipta, 2003).

17. Moehji, S. Imu Gizi 2. (Papas Sinar Sinart, 2009).

18. Rahmawati, F. \& Wahyuni, I. Hubungan Antara Beban Kerja Fisik Dengan Tingkat Kebugaran Jasmani Pekerja Bagian Ground Handling Di Bandara Ahmad Yani Semarang (Studi Kasus pada Pekerja Porter PT. Gapura Angkasa). J. Kesehat. Masy. 4, 383-393 (2016).

19. Syarif, A.A., Sinulingga, S. and Nazaruddin, N. Penentuan Faktor yang Mempengaruhi Produktivitas Tenaga Kerja di PT. Intan Suar Kartika dan Rancangan Strategi Perbaikan. J. Teknovasi J. Tek. dan Inovasi, 1(2), 8-14 (2018).

20. Astuti P, P. S. Hubungan Asupan Energi, Asupan Protein Dan Status Gizi Dengan Produktivitas Kerja Pada Tenaga Kerja Wanita Bagian Finishing 3 Pt Hanil Indonesia Nepen Teras Boyolali. (Universitas Muhammadiyah
Surakarta, 2017).

21. S., W. Faktor Determinan Produktivitas Kerja pada Pekerja Wanita. (Universitas Diponegoro, 2011).

22. Oktapianti, Y. I. Hubungan Antara Asupan Energi, Protein, Lemak, Karbohidrat Dan Aktivitas Fisik Dengan Produktivitas Kerja Pada Pekerja Wanita Di Konveksi Rizkya Batik Ngemplak Boyolali. (Universitas Muhammadiyah Surakarta, 2014).

23. TRANSMIGRASI, S. E. M. T. K. D. Tentang Pengadaan Kantin Dan Ruang Tempat Makan. (1979).

24. Suma'mur, P. . Higiene perusahaan dan kesehatan kerja. (Sagung Seto, 2009).

25. Sari, A. R. \& Muniroh, L. Hubungan Kecukupan Asupan Energi dan Status Gizi dengan Tingkat Kelelahan Kerja Pekerja Bagian Produksi ( Studi di PT . Multi Aneka Pangan Nusantara Surabaya ) Relationship between Sufficient Intake of Energy, Nutritional Status and the Level of Labor Exhaustion among Production Workers ( Study at PT Multi Aneka Pangan Nusantara Surabaya ). 275-281 (2017). doi:10.20473/amnt.v1.i4.2017.275-281

26. Nur Herawati, H. S. Analisis Pengaruh Pendidikan, Upah Pengalaman Kerja, Jenis Kelamin Dan Umur Terhadap Produktivitas Tenaga Kerja Industri Shutllecock Kota Tegal. DIPONEGORO J. Econ. 2, 1-8 (2013).

27. Kaur, J. A comprehensive review on metabolic syndrome vol. (2014): 943162. doi: Cardiol. Res. Pract. (2014).

28. Sedarmayanti. Tata Kerja dan Produktivitas Kerja. (CV. Mandar Maju, 2011).

29. Hartutik, S. Hubungan Obesitas Dengan Nyeri Persendian Lutut Pada Lansia. J. Kesehat. 16, 206-215. (2018).

30. Sharifzadeh, M. Does Fitness and Exercises Increase Productivity? Assessing Health, Fitness and Productivity Relationship Mansour Sharifzadeh California State Polytechnic University Pomona. 13, 32-52 (2013). 